\title{
Penerapan Model Pembelajaran Group Investigation untuk Meningkatkan Hasil Belajar Matematika Siswa Kelas V
}

\section{Kadek Sri Trisna Devi ${ }^{*}$, I Made Citra Wibawa ${ }^{2}$, I Kadek Agus Sudiandika ${ }^{3}$}

\footnotetext{
1,2 Universitas Pendidikan Ganesha, Singaraja, Indonesia
}

${ }^{3}$ Sekolah Dasar Negeri 3 Temukus, Singaraja, Indonesia

\section{ART I CLE IN F O}

Article history:

Received April 09, 2021

Revised April 15, 2021

Accepted July 30, 2021

Available online August 25, 2021

Kata Kunci:

Group Investigation, Hasil

Belajar Matematika

Keywords:

Group Investigation, Math

Learning Outcomes

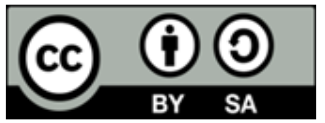

This is an open access article under the CC BY-SA license.

Copyright () 2021 by Author. Published by Universitas Pendidikan Ganesha.

\begin{abstract}
A B S T R A K
Penelitian ini dilakukan karena hasil belajar matematika siswa kelas $\mathrm{V}$ dengan hasil tes belum optimal dan pembelajaran masih bersifat konvensional (teacher centered). Penelitian ini bertujuan untuk mengetahui peningkatan hasil belajar matematika melalui model pembelajaran group investigation. Penelitian tindakan kelas dilaksanakan di SD Negeri 1 Anturan Propinsi Bali dengan mengambil Subjek penelitian sebanyak 31 orang. Penelitian ini dilakukan dalam 2 siklus. Setiap siklus terdiri dari kegiatan perencanaan, pelaksanaan, observasi, dan refleksi. Data dikumpulkan dengan tes berbentuk pilihan ganda dengan jumlah soal sebanyak 20 butir. Data hasil belajar dianalisis dengan metode analisis deskriptif kuantitatif yaitu dengan mencari rata-rata nilai siswa dan ketuntasan belajar. Data diambil dari tiga kegiatan yaitu pra siklus, siklus I dan siklus II. Data hasil belajar yang diperoleh siswa pra siklus yaitu dengan nilai rata-rata 64,35 dan ketuntasan belajar mencapai $48,39 \%$, siklus I mengalami peingkatan dengan nilai rata-rata sebesar 68,55 ketuntasan belajar mencapai $58,06 \%$, dan siklus II memperoleh nilai ratarata 76,13 dan ketuntasan belajar $83,87 \%$. Dalam penelitian in dapat disimpulkan bahwa penerapan model pembelajaran group investigation dapat meningkatkan hasil belajar matematika siswa kelas V.
\end{abstract}

\section{A BS TRACT}

This research was conducted because the mathematics learning outcomes of fifth grade students with test results were not optimal and learning was still conventional (teacher centered). This study aims to determine the improvement of mathematics learning outcomes through the group investigation learning model. The research subjects were students of class $V$, totaling 31 people. Data were collected by means of multiple choice tests with a total of 20 questions. Learning outcomes data were analyzed by quantitative descriptive analysis method, namely by finding the average student score and learning completeness. Data were taken from three activities, namely pre-cycle, cycle I and cycle II. Learning outcomes data obtained by pre-cycle students with an average value of 64.35 and learning completeness reached $48.39 \%$, the first cycle experienced an increase with an average value of 68.55 , learning completeness reached $58.06 \%$, and the second cycle obtained an average value of 76.13 and completeness study $83.87 \%$. It can be concluded that the application of the group investigation learning model can improve the mathematics learning outcomes of fifth grade students.

\section{PENDAHULUAN}

Matematika merupakan salah satu bidang studi yang dijarkan di sekolah baik sekolah dasar, sekolah mengengah pertama, maupun sekolah menengah atas. Matematika adalah ilmu tentang bilangan, ruang, bahasa simbol dan numerik (Maarif, 2015; Rahmah, 2018). Konsep matematika didapat karena proses berpikir. Oleh karena itu, logika adalah dasar terbentuknya matematika (Kurniati, 2016). Dalam pembelajaran matematika, kreativitas siswa sangat dibutuhkan terutama dalam menyelesaikan soal-soal yang melibatkan siswa untuk berpikir kreatif. Dengan demikian, siswa diharapkan dapat mengemukakan ide-ide baru yang kreatif dalam menganalisis dan menyelesaikan soal (Khairani \& Ismah, 2016). Pembelajaran matematika bertujuan agar siswa dapat memahami konsep matematika yang bersifat abstrak dan mampu menerapkan dalam kehidupan sehari-hari (Jaziroh, 2019). Matematika sangat diperlukan untuk kehidupan sehari-hari maupun dalam menghadapi kemajuan IPTEK (Wana et al., 2017). 
Matematika selain dapat memperluas cakrawala berpikir peserta didik juga dapat mengembangkan kesadaran tentang nilai-nilai yang secara esensial terdapat di dalamnya. Maka dari itu, matematika sangat penting diajarkan kepada siswa di sekolah, khususnya di sekolah dasar. Pembelajaran matematika dapat dikatakan berhasil jika tujuan pembelajaran yang telah ditentukan dapat tercapai (Juliawan et al., 2017). Kekreatifan guru dalam mendesain pembelajaran sangat dibutuhkan agar suksesnya pembelajaran (Ulhusna \& Diana, 2020).

Berdasarkan studi awal yang dilakukan, pembelajaran matematika yang dilaksanakan pada 21 Januari 2021 di SD Negeri 1 Anturan, Kecamatan Buleleng diketahui bahwa proses Matematika dibelajarkan secara daring sesuai dengan situasi pandemi Covid-19 saat ini. Ketika pelaksanaan observasi pembelajaran, ditemukan beberapa permasalahan, diantaranya: pembelajaran masih bersifat konvensional (Teacher Centered), media yang digunakan kurang bervariasi, sehingga siswa cepat merasa bosan, siswa kurang termotivasi dalam menyelesaikan tugas dengan tepat waktu, dan guru kurang mengaitkan materi pelajaran dengan konteks kehidupan nyata. Permasalahan tersebut didukung dengan perolehan hasil belajar siswa kelas V SDN 1 Anturan dengan hasil tes formatif Matematika belum optimal. Diperoleh niai rata-rata nilai sebesar 64. Dari 31 orang siswa hanya 15 orang dengan persentase $48.39 \%$ siswa yang tuntas dengan nilai di atas KKM yang sudah ditetapkan yaitu sebesar 65. Sedangkan 16 orang siswa dengan persentase $51.61 \%$ belum tuntas atau masih berada di bawah nilai KKM. Dengan data hasil belajar dan pelaksanakan mata pelajaran tersebut, maka perlu proses pembelajaran yang lebih baik agar siswa aktif dalam pembelajaran, sehingga dapat meningkatkan kualitas pembelajaran matematika. Masalah tersebut juga sejalan dengan penelitian sebelumnya yang menyatakan bahwa pembelajaran didominasi oleh metode ceramah dan tanya jawab (Irwan \& Sani, 2015; Nadiya et al., 2016). Guru lebih berorientasi pada materi pelajaran dengan alasan tuntutan kurikulum untuk mempersiapkan peserta didik dalam menghadapi ulangan (Ayuwanti, 2016; Muliyantini \& Parmiti, 2017). Guru menginformasikan konsep-konsep yang terdapat pada buku pelajaran secara rinci diselingi dengan tanya jawab. Proses pembelajaran di SD cenderung menggunakan pembelajaran konvensional. Dalam hal ini pembelajaran konvensional yang dimaksudkan adalah pembelajaran dengan menggunakan medote ceramah, yaitu pembelajaran yang lebih banyak didominasi gurunya sebagai pentransfer ilmu, sementara siswa lebih pasif sebagai penerima ilmu (Dewi et al., 2017; Ningsih, 2019). Hal ini membuat siswa kurang termotivasi dan cepat merasa bosan dalam menerima pembelajaran. Lemahnya penguasaan matematika diperparah oleh keterbatasan waktu seorang guru kelas di SD karena beban mengajar tidak hanya satu mata pelajaran, melainkan hampir semua mata pelajaran (Darjiani et al., 2015; Kadek et al., 2017). Proses pembelajaran seperti ini dapat mengakibatkan pembelajaran menjadi kurang bermakna dan siswa menjadi kurang paham dengan muatan materi yang dipelajari. Pembelajaran matematika di sekolah dasar hendaknya membuka kesempatan untuk memupuk rasa ingin tahu siswa. Hal ini akan membantu mereka mengembangkan kemampuan bertanya dan mencari jawaban berdasarkan bukti serta mengembangkan cara berpikirnya. Jadi, penyebab hasil belajar siswa rendah salah satunya yaitu pembelajaran masih bersifat konvensional yang menyebabkan motivasi siswa dalam belajar semakin menurun. Jika hal ini dibiarkan, maka hasil belajar matematika siswa tidak mengalami peningkatan.

Berdasarkan permasalahan yang ditemukan, maka perlu adanya solusi yang inovatif dan dapat meningkatkan hasil belajar melalui penerapan suatu model pembelajaran yang lebih berpusat pada upaya menumbuhkembangkan partisipasi dan aktivitas siswa. Dalam hal ini kegiatan pembelajaran tidak lagi hanya mengutamakan produk, akan tetapi lebih mengutamakan proses yang dialami siswa dalam pemerolehan pengetahuan. Pembelajaran yang baik adalah suatu pembelajaran yang memiliki aspek membangun pengetahuan siswa terhadap materi tertentu. Salah satu model pembelajaran yang memiliki aspek membangun pengetahuan siswa adalah model pembelajaran kooperatif tipe group investigation (GI). Model pembelajaran ini dapat digunakan untuk meningkatkan aktivitas peserta didik dan kemampuan kerja sama antara peserta didik. adalah. Peserta didik belajar dalam kelompok-kelompok kecil yang saling membantu dan melakukan investigasi untuk menemukan dan menyelesaikan masalah. Model kooperatif tipe group investigation (GI) dipilih untuk meningkatkan hasil belajar karena dapat melibatkan peserta didik secara aktif dalam proses belajar mengajar dan terlibat langsung menentukan masalah yang akan diinvestigasi. Model pembelajaran kooperatif tipe GI adalah salah satu bentuk model pembelajaran kooperatif yang memiliki titik tekan pada partisipasi dan aktivitas siswa untuk mencari sendiri materi atau segala sesuatu mengenai materi pelajaran yang akan dipelajari.

Model pembelajaran group investigation menekankan pada aktivitas siswa untuk menemukan sendiri informasi pelajaran melalui lingkungan sekitarnya atau alat-alat yang tersedia (Putra et al., 2018; Sutrini et al., 2013). Keuntungan bagi peserta didik dengan digunakannya model pembelajaran kooperatif tipe GI antara lain adalah dapat bekerja secara bebas dalam proses belajar, dapat belajar untuk memecahkan dan menangani suatu masalah, dapat memberi semangat untuk berinisiatif, kreatif, dan aktif, meningkatkan belajar bekerja sama, belajar menghargai pendapat orang lain, meningkatkan 
partisipasi dalam membuat suatu keputusan, dan terlatih untuk mempertanggungjawabkan jawaban yang disampaikannya (Sai, 2017; Wahyuni et al., 2018). Dengan model pembelajaran Group Investigation peserta didik mampu bekerja secara aktif untuk memahami, memaknai, mengidentifikasi, serta mampu menjelaskan kembali konsep secara terperinci (E. Lestari et al., 2019; Zainuddin, 2013). Penerapan model pembelajaran Group Investigation (GI) dapat meningkatkan faktor-faktor yang memengaruhi kompetensi pengetahuan (Widiartini, 2019). Siswa saling bekerja sama memecahkan masalah melalui hubungan yang harmonis sesama teman. Kegiatan ini membuat siswa merasa bersemangat dan senang mengikuti pembelajaran. Selain itu, interaksi siswa dapat juga ditingkatkan melalui berdiskusi dan berinteraksi dengan temannya dalam menemukan dan memahami suatu konsep (S. Lestari, 2017; Pratami et al., 2019). Penerapan model pembelajaran kooperatif tipe group investigation memberi keunggulan yang bernuansa pada pembelajaran ideal, yakni suasana belajar yang menyenangkan saling berinteraksi dan bekerja sama secara heterogen tanpa memandang latar belakang serta mampu melatih kemampuan siswa dalam berpendapat dan berkomunikasi yang baik (Ismiyati, 2015; Widiasari \& Sumantri, 2020). Dengan berkelompok siswa akan semangat dalam mengerjakan tugas yang diberikan guru. Proses belajar menggunakan Group Investigation memberikan kesempatan seluasluasnya kepada siswa untuk terlibat secara langsung dan aktif dalam proses pembelajaran (Supriyanto, 2020).

Beberapa penelitian yang sudah dilakukan yang berkaiatan dengan model pembelajaran group investigation, antara lain penelitian yang menyatakan bahwa model Group Investigation yang diterapkan sesuai langkah-langkah yang tepat dapat meningkatkan keterampilan berpikir kritis siswa(Supriyanto \& Mawardi, 2020). Penelitian yang menyatakan bahwa pembelajaran menggunakan model pembelajaran kooperatif tipe Group Investigation (GI) dapat meningkatkan hasil belajar siswa (Ayuwanti, 2017). Penelitian yang menyatakan bahwa model pembelajaran kooperatif tipe group investigation berpengaruh positif terhadap kreativitas atau kemampuan berpikir kreatif mahasiswa (Lilik, 2017). Penelitian yang menyatakan bahwa model pembelajaran kooperatif tipe Group Investigation dapat meningkatkan aktivitas dan hasil belajar siswa (Febrianti et al., 2018). Penelitian yang menyatakan bahwa terdapat pengaruh yang signifikan antara kemampuan pemahaman konsep matematis siswa yang belajar menggunakan model kooperatif tipe Group Investigation (GI) dengan siswa yang belajar menggunakan pembelajaran konvensional (Yuliani et al., 2018). Selama ini sudah banyak penelitian mengenai model pembelajaran group investigation. Yang menjadikan penelitian ini berbeda dengan penelitian sebelumnya yaitu penerapan model pembelajaran yang dilaksanakan dalam bentuk daring menggunakan aplikasi google meet dan whatsapp serta menayangkan video pembelajaran yang dapat menguatkan pemahaman siswa mengenai materi yang didapat. Berdasarkan pemaparan tersebut, maka dirumuskan tujuan penelitian yaitu meningkatkan hasil belajar matematika dengan menerapkan model group investigation pada siswa kelas V SDN 1 Anturan.

\section{METODE}

Penelitian yang dilaksanakan ini termasuk jenis penelitian tindakan kelas. PTK merupakan salah satu teknik agar pembelajaran yang dikelola guru selalu mengalami peningkatan melalui perbaikan secara terus-menerus (Sanjaya, 2016). Penelitian tindakan kelas adalah penelitian yang dilakukan untuk meningkatkan beberapa praktik pendidikan (Anugrah, 2019). Oleh sebab itu, melaksanakan penelitian tindakan kelas erat kaitannya dengan pelaksanaan tugas profesional yang harus dikuasi kuasai oleh setiap guru. Subjek penelitian ini adalah siswa kelas V SDN 1 Anturan tahun ajaran 2020/2021. Adapun siswa kelas V sebanyak 31 siswa yang terdiri dari 18 siswa laki-laki dan 13 siswa perempuan. Penulisan prosedur penelitian tidak bisa dilepaskan dari rancangan yang telah dibuat. Penelitian ini dilakukan dalam beberapa siklus, tiap siklus terdiri atas empat kegiatan yaitu 1) perencanaan, 2) pelaksanaan, 3) observasi, dan 4) refleksi. Rancangan penelitiannya seperti pada Gambar 1.

Penelitian ini menggunakan teknik pengumpulan data berupa tes. Teknik tes digunakan untuk memperoleh data tentang hasil belajar Matematika. Teknik tes dalam hal ini adalah pos-tes dilaksanakan sebanyak dua kali yaitu pos-tes siklus I dan pos-tes siklus II. Pos-tes siklus I diberikan setelah pertemuan ke tiga dari siklus I berakhir, sedangkan pos-tes siklus II diberikan setelah pertemuan ke tiga dari siklus II berakhir. Tujuan pemberian pos-tes pada akhir siklus yaitu untuk mengetahui hasil belajar Matematika siswa setelah diberikan tindakan atau perlakukan. Instrumen pengumpulan data yang digunakan pada penelitian ini berupa butir soal pilihan ganda yang berjumlah 20 butir soal. Soal dijawab oleh setiap siswa secara tertulis pada lembar jawaban yang sudah disediakan dengan tujuan untuk mengetahui hasil belajar siswa pada mata pelajaran Matematika. Untuk menentukan secara jelas ruang lingkup penelitian dan sebagai petunjuk dalam menulis butir instrumen, harus ditentukan kisi-kisi dari instrumen yang akan 
disusun. Kisi-kisi instrumen disusun berdasarkan objek pelaksanaan tindakan yang dilakukan di kelas. Adapun kisi-kisi instrumen dapat dilihat pada Tabel 1.

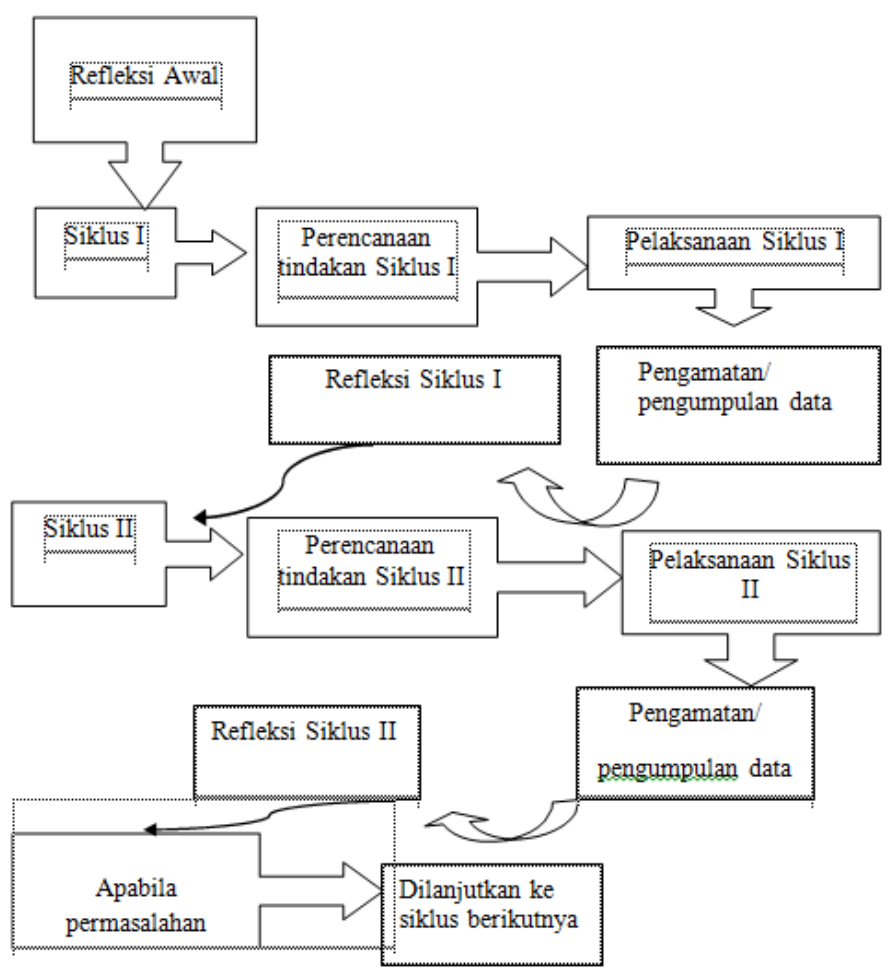

Gambar 1. Spiral Rancangan Penelitian Tindakan Kelas (Nurdin, 2016)

Tabel 1. Kisi-kisi Instrumen

\begin{tabular}{|c|c|c|c|c|c|}
\hline \multicolumn{2}{|r|}{ KD } & \multicolumn{2}{|r|}{ Indikator } & \multirow{2}{*}{$\begin{array}{c}\begin{array}{c}\text { Tingkat } \\
\text { Kognitif }\end{array} \\
\text { C4 }\end{array}$} & \multirow{2}{*}{$\frac{\text { Keterangan }}{\text { Siklus I }}$} \\
\hline \multirow[t]{12}{*}{3.5} & $\begin{array}{l}\text { Menjelaskan, } \\
\text { dan }\end{array}$ & 3.5 .1 & $\begin{array}{l}\text { Menganalisis sifat-sifat bangun ruang balok } \\
\text { dan kubus. }\end{array}$ & & \\
\hline & $\begin{array}{l}\text { menentukan } \\
\text { volume }\end{array}$ & 3.5 .2 & $\begin{array}{l}\text { Menemukan sifat-sifat bangun ruang balok } \\
\text { dan kubus. }\end{array}$ & C6 & \\
\hline & $\begin{array}{l}\text { bangun ruang } \\
\text { dengan }\end{array}$ & 3.5 .3 & $\begin{array}{l}\text { Mengukur volume balok dengan kubus } \\
\text { satuan. }\end{array}$ & C5 & \\
\hline & $\begin{array}{l}\text { menggunakan } \\
\text { satuan volume }\end{array}$ & 3.5 .4 & $\begin{array}{l}\text { Menemukan volume balok dengan kubus } \\
\text { satuan. }\end{array}$ & C6 & \\
\hline & $\begin{array}{l}\text { (seperti kubus } \\
\text { satuan) serta }\end{array}$ & 3.5 .5 & $\begin{array}{l}\text { Mengukur volume balok bila diketahui } \\
\text { ukuran tertentu. }\end{array}$ & C5 & \\
\hline & $\begin{array}{l}\text { hubungan } \\
\text { pangkat tiga }\end{array}$ & 3.5 .6 & $\begin{array}{l}\text { Menemukan volume balok bila diketahui } \\
\text { ukuran tertentu. }\end{array}$ & C6 & \\
\hline & $\begin{array}{l}\text { dengan akar } \\
\text { pangkat tiga. }\end{array}$ & 3.5 .7 & $\begin{array}{l}\text { Mengukur volume kubus dengan kubus } \\
\text { satuan. }\end{array}$ & C5 & Siklus II \\
\hline & & 3.5 .8 & $\begin{array}{l}\text { Menemukan volume balok dengan kubus } \\
\text { satuan. }\end{array}$ & C6 & \\
\hline & & 3.5 .9 & $\begin{array}{l}\text { Mengukur volume kubus bila diketahui } \\
\text { ukuran tertentu. }\end{array}$ & C5 & \\
\hline & & 3.5 .10 & $\begin{array}{l}\text { Menemukan volume kubus bila diketahui } \\
\text { ukuran tertentu. }\end{array}$ & C6 & \\
\hline & & 3.5 .11 & $\begin{array}{l}\text { Menemukan panjang rusuk kubus apabila } \\
\text { diketahui volumenya. }\end{array}$ & C6 & \\
\hline & & 3.5 .12 & $\begin{array}{l}\text { Menemukan akar pangkat tiga dari } \\
\text { bilangan tertentu. }\end{array}$ & C6 & \\
\hline
\end{tabular}


Data hasil belajar yang telah diperoleh akan dianalisis dengan metode analisis deskriptif kuantitatif. "Metode analisis deskritif kuantitatif adalah suatu cara pengolahan data yang dilakukan dengan jalan menyusun secara sistematis dalam bentuk angka-angka maupun peresntase mengenai keadaan suatu objek yang diteliti, sehingga diperoleh kesimpulan umum" Agung (2010). Analisis data yang menyangkut hasil belajar siswa menggunakan analisis deskriptif kuantitatif yaitu dengan mencari rata-rata nilai siswa dan ketuntasan belajar siswa. Hasil analisis tingkat hasil belajar siswa yang diperoleh berdasarkan rata- rata nilai siswa dan ketuntasan belajar. Selanjutnya, hasilnya dikonversi ke dalam Penilaian Acuan Patokan (PAP) skala lima dengan berpedoman pada kriteria pada tabel 2.

Tabel 2. Kriteria Penilaian Acuan Patokan (PAP) Skala Lima Tentang Hasil Belajar Siswa

\begin{tabular}{cc}
\hline Tingkat penguasaan & Kategori \\
\hline $85 \%-100 \%$ & Sangat Tinggi \\
$70 \%-84 \%$ & Tinggi \\
$55 \%-69 \%$ & Cukup \\
$40 \%-54 \%$ & Rendah \\
$0-39 \%$ & Sangat Rendah \\
\hline
\end{tabular}

(Agung, 2010)

Keberhasilan suatu penelitian dapat dilihat dari kemajuan hasil belajar yang dicapai oleh siswa sesuai dengan KKM yang ditetapkan oleh sekolah yaitu memperoleh nilai secara individu minimal 65 . Adapun indikator keberhasilan yang diinginkan oleh peneliti dalam penelitian ini yaitu rata-rata hasil belajar siswa secara klasikal mencapai 70 dengan kategori tinggi dan ketuntasan belajar klasikal yang dicapai sebesar 80\% dengan kategori tinggi.

\section{HASIL DAN PEMBAHASAN}

Hasil

Hasil belajar siswa yang diperoleh dari sebelum diadakannya peneltian (prasiklus) hingga sesudah diadakannya penelitian (Silus I dan II) yang dapat dilihat pada tabel 3.

Tabel 3. Rekapitulasi Hasil Belajar Pra Siklus, Siklus I, Siklus II

\begin{tabular}{clccc}
\hline No & \multicolumn{1}{c}{ Aspek } & Pra siklus & Siklus I & Siklus II \\
\hline 1 & Jumlah Seluruh Siswa & 31 & 31 & 31 \\
2 & Jumlah Nilai & 1995 & 2125 & 2360 \\
3 & KKM & 64.35 & 65 & 65 \\
4 & Nilai Rata-rata & 65 & 68.55 & 76.13 \\
5 & Nilai Tertinggi & 80 & 85 & 95 \\
6 & Nilai Terendah & 50 & 50 & 50 \\
7 & Jumlah Siswa Tuntas & 15 & 18 & 26 \\
8 & Jumlah Siswa Tidak Tuntas & 16 & 13 & 5 \\
9 & Persentase Ketuntasan Belajar & $48.39 \%$ & $58.06 \%$ & $83.87 \%$ \\
\hline
\end{tabular}

Berdasarkan tabel 3 hasil belajar pada pra siklus menunjukan kondisi awal siswa pada pembelajaran sebelumnya. Merujuk pada hasil Penilaian Akhis Semester (PAS) Ganjil tahun pelajaran 2020/2021 ditemukan lebih banyak siswa yang tidak tuntas dari KBM sekolah yang telah ditentukan yaitu 65. Kegiatan yang dilaksanakan pada siklus I adalah mengukur hasil belajar siswa setelah dilaksanakannya pemberian post-tes siklus I berupa soal objektif sebanyak 20 butir soal. Berdasarkan persentase ketuntasan belajar siklus 1, maka penelitian ini dinyatakan belum berhasil karena melihat kriteria ketuntasan belajar yang ditetapkan sebesar $80 \%$, sedangkan persentase hasil ketuntasan belajar secara klasikal mencapai 58.06\%. Merujuk dari hasil tersebut, maka penelitian dilanjutkan pada pelaksanaan siklus II. Setelah hasil belajar siswa pada siklus II dibandingkan ke dalam PAP skala lima, maka tingkat hasil belajar siswa pada siklus II berada pada kategori tinggi. Hal ini menunjukkan terjadinya peningkatan hasil belajar siswa dari kegiatan sebelumnya. Merujuk dari hasil tersebut, maka penelitian ini dinyatakan sudah berhasil karena sudah sesuai dengan ketuntasan belajar yang ditetapkan. Berdasarkan hasil penelitian, peningkatan hasil belajar matematika siswa kelas V SD Negeri 1 Anturan pada kegiatan pra siklus, siklus I, dan siklus II yang telah dilaksanakan diperoleh hasil peningkatan hasil penelitian pada Tabel 6 berikut. 
Tabel 4. Peningkatan Hasil Belajar Matematika Siswa Kelas V

\begin{tabular}{llllll}
\hline & Pra siklus & Peningkatan & Siklus I & Peningkatan & Siklus II \\
\hline $\begin{array}{l}\text { Rata-rata nilai siswa } \\
\begin{array}{l}\text { Ketuntasan belajar } \\
\text { siswa }\end{array}\end{array}$ & 64.35 & 4.2 & 68.55 & 7.58 & 76,13 \\
Kategori PAP & Rendah & $9,67 \%$ & $58.06 \%$ & $25.81 \%$ & $83,87 \%$ \\
\hline
\end{tabular}

Berdasarkan hasil penelitian dalam bentuk tabel 3, penelitian tindakan kelas yang dilaksanakan pada siswa kelas V di SD Negeri 1 Anturan dilakukan dalam 2 siklus. Setiap siklus terdiri dari kegiatan perencanaan, pelaksanaan, observasi, dan refleksi. Kondisi awal hasil belajar matematika siswa kelas $\mathrm{V}$ berdasarkan nilai PAS Semester I pada tabel 3 didapatkan data awal bahwa nilai rata-rata siswa mencapai 64.35 dengan ketuntasan belajar mencapai 48.39\%, dan jika dikategorikan pada PAP skala lima berada pada kategori rendah. Hal ini menjadi dasar diadakannya penelitian tindakan kelas dengan menerapkan model pembelajaran Group Investigation untuk meningkatkan hasil belajar matematika siswa kelas V.

Hasil penelitian siklus I pada tabel 4 diperoleh nilai rata-rata siswa sebesar 68.55 dengan ketuntasan belajar 58.06\% dan jika dikategorikan pada PAP skala lima berada pada kategori cukup. Adapun permasalahan yang dihadapi pada siklus I yaitu: (1) jumlah siswa yang bisa mengikuti pembelajaran dengan google meet masih sangat sedikit, (2) siswa masih belum terbiasa menggunakan google meet ketika proses pembelajaran, sehingga microfon dan kamera belum dapat digunakan dengan baik, (3) siswa belum percaya diri menyampaikan hasil kerja yang telah dilakukan. Berdasarkan permasalahan tersebut, solusi yang dilakukan yaitu: (1) materi pembelajaran dan LKPD dibagikan melalui whatsapp group, sehingga semua siswa dapat mengikuti pembelajaran dengan baik, (2) membuat aturan pembelajaran ketika pelaksanaan google meet untuk mengurangi kebisingan ketika proses pembelajaran berlangsung, (3) memberikan semangat dan motivasi kepada siswa untuk meningkatkan rasa percaya diri ketika menyampaikan hasil kerja. Berdasarkan uraian tersebut, jika dilihat dari nilai rata-rata siswa, ketuntasan belajar dan permasalahan yang dihadapi pada penelitian siklus I belum mencapai ketuntasan hasil belajar yang telah ditetapkan, maka penelitian dilanjutkan pada siklus II.

Hasil penelitian siklus II pada tabel 4 didapatkan nilai rata-rata siswa sebesar 76,13 dengan ketuntasan belajar mencapai $83,87 \%$ dan jika dikategorikan pada PAP skala lima berada pada kategori tinggi. Hal ini menunjukkan bahwa pada siklus II terdapat peningkatan hasil belajar siswa yang sudah mencapai ketentuan yang telah ditetapkan. Peningkatan hasil belajar siswa dari prasiklus menuju siklus I jika dilihat dari nilai rata-rata siswa meningkat sebanyak 4.2 dan ketuntasan belajar meningkat sebanyak 9.67\%. Sedangkan peningkatan hasil belajar dari siklus I menuju siklus II jika dilihat dari nilai rata-rata yaitu sebesar 7.58 dan ketuntasan belajar meningkat sebanyak 25.81\%. Peningkatan hasil belajar matematika siswa kelas V tersebut menunjukkan bahwa dengan menerapkan model pembelajaran Group Investigation siswa dapat memecahkan permasalahan sesuai dengan materi pembelajaran, keaktifan siswa juga terlihat meningkat dengan adanya pemberian video pembelajaran yang lebih menarik dan sesuai dengan materi serta karakteristik siswa. Kemampuan berpikir tingkat tinggi yang dimiliki siswa dapat melatih pola pikir untuk lebih kreatif dan inovatif dalam memecahkan permasalahan yang diberikan. Jadi, penerapan model pembelajaran group investigation dapat meningkatkan hasil belajar matematika siswa kelas V, hal ini disebabkan oleh beberapa faktor yaitu sebagai berikut. Pertama model kooperatif tipe group Investigation dalam pelaksanaannya terdapat kegiatan kerja sama dengan kelompok pada tahap investigasi dalam menyelesaikan masalah yang diberikan. Pelaksanaan model group Investigation menekankan pada partisipasi dan aktivitas siswa untuk mencari sendiri pengetahuan tentang materi yang dipelajari dengan sumber belajar yang sudah ada dilingkungan tempat belajarnya dan mendiskusikannya ersama anggota kelompoknya (Widiasari \& Sumantri, 2020). Dengan adanya kerja sama yang baik antar anak akan membatu proses belajar lebih baik karena mereka saling memberikan apa yang mereka ketahui. Mereka saling membantu untuk tercapainya tujuan yang yang ingin dicapai yaitu kesuksesan belajar bersama, sehingga anak yang mempunyai kemampuan yang berbeda saling melengkapi. Dengan adanya pembelajaran dengan teman sebaya akan mendorong peserta didik untuk berperan aktif dalam pembelajaran (Oh, 2019). Metode teman sebaya meningkatakan pembelajaran peserta didik melalui pengalaman yang merupakan umpan balik dari temannya (Gabriele et al., 2016). Teman sebaya membantu, membimbing, dan mendukung sesama teman sebaya, sehingga mereka mampu membangun pembelajaran melalui interaksi dan kolaborasi (Andersen \& Watkins, 2018). Pembelajaran yang melibatkan teman sebaya akan mengurangi kecemasan dan setres Dengan dibimbing, dibantu, dan diberikan umpan balik oleh teman sebaya, peserta didik akan dapat meningkatkan kepercayaan diri (Han et al., 2015; Stone et al., 2013). Berdasarkan jabaran-jabaran tersebut, untuk menciptakan pembelajaran 
yang kondusif dan sesaui dengan kondisi saat ini, haruslah dilaksanakan pembelajaran yang memberikan kesempatan kepada peserta didik untuk berbagi harapan belajar.

Kedua adalah model kooperatif tipe group Investigation memberikan kesempatan siswa untuk menyampaikan pendapat, berdiskusi, dan mencari tahu kebenaran dari tugas yang dibuat dengan cara bertanya maupun mengemukakan ide yang mereka miliki. Siswa dibimbing untuk mengembangkan pendapat-pendapat yang telah direncanakan (Supriyanto, 2020). Kegiatan ini membuat siswa menjadi lebih memahami apa yang mereka pelajari karena siswa mencari tahu sendiri kebenaran tugas tersebut. Model pembelajaran group Investigation mengajak siswa untuk berperan aktif dalam mengungkapkan pendapatnya (Muliyantini \& Parmiti, 2017). Model pembelajaran kooperatif tipe GI antara lain adalah dapat bekerja secara bebas dalam proses belajar, dapat belajar untuk memecahkan dan menangani suatu masalah, dapat memberi semangat untuk berinisiatif, kreatif, dan aktif, meningkatkan belajar bekerja sama, belajar menghargai pendapat orang lain, meningkatkan partisipasi dalam membuat suatu keputusan, dan terlatih untuk mempertanggungjawabkan jawaban yang disampaikannya (Sai, 2017; Wahyuni et al., 2018). Dengan model pembelajaran Group Investigation peserta didik mampu bekerja secara aktif dalam untuk memahami, memaknai, mengidentifikasi, serta mampu menjelaskan kembali konsep secara terperinci (E. Lestari et al., 2019; Zainuddin, 2013).

Ketiga, pencapaian keberhasilan siswa dalam menguasai materi juga sangat dipengaruhi oleh sintaks model pembelajaran kooperatif tipe group investigation. Setiap sintaks tersebut memiliki keunggulan yang mampu memengaruhi keaktifan siswa dalam memperoleh pengetahuan dan kebiasaan berkomunikasi secara interaktif, sehingga pembelajaran lebih berpusat kepada siswa. Sintaks model pembelajaran kooperatif tipe group investigation yang dimaksud, yaitu: grouping, planning, investigation, organizing, presenting, dan evaluating. Group Investigation (GI) terdiri atas beberapa langkah yaitu identifikasi topik dan mengatur siswa dalam kelompok, merencanakan tugas, investigasi, membuat laporan akhir, presentasi hasil laporan akhir, dan evaluasi (Ismiyati, 2015). Model pembelajaran kooperatif tipe group investigation memberikan nilai positif dalam pelaksanaan pembelajaran yaitu pembelajaran berpusat pada siswa, sehingga siswa memiliki kebebasan untuk mencari, membentuk, dan mengembangkan konsep sesuai kemampuannya. Sintaks yang terdapat pada model pembelajaran kooperatif tipe group investigation membantu siswa untuk menguasai konsep-konsep tertentu dan mengembangkan interaksi, kerja sama, dan keterlibatan siswa dalam pembelajaran (Ariadi, 2014).

Temuan ini juga didukung oleh beberapa penelitian sebelumnya yang menyatakan bahwa terdapat peningkatkan aktivitas dan hasil belajar matematika menggunakan model pembelajaran kooperatif tipe group investigation di SMK Tuma'ninah Yasin Metro (Ayuwanti, 2016). Penerapan model pembelajaran group investigation (GI) dapat meningkatkan hasil belajar ipa kelas V (Muliyantini \& Parmiti, 2017). Penerapan model pembelajaran group investigation (GI) dapat meningkatkan keterampilan berpikir kritis siswa pada materi gerak lurus kelas X (Nadiya et al., 2016). Penelitian yang menyatakan bahwa model Group Investigation yang diterapkan sesuai langkah-langkah yang tepat dapat meningkatkan keterampilan berpikir kritis siswa (Supriyanto \& Mawardi, 2020). Penelitian yang menyatakan bahwa pembelajaran menggunakan model pembelajaran kooperatif tipe Group Investigation (GI) dapat meningkatkan hasil belajar siswa (Ayuwanti, 2017). Penelitian yang menyatakan bahwa Model pembelajaran kooperatif tipe group investigation berpengaruh positif terhadap kreativitas atau kemampuan berfikir kreatif mahasiswa (Lilik, 2017). Penelitian yang menyatakan bahwa model pembelajaran kooperatif tipe Group Investigation dapat meningkatkan aktivitas dan hasil belajar siswa (Febrianti et al., 2018). Penelitian yang menyatakan bahwa terdapat pengaruh yang signifikan antara kemampuan pemahaman konsep matematis siswa yang belajar menggunakan model kooperatif tipe Group Investigation (GI) dengan siswa yang belajar menggunakan pembelajaran konvensional (Yuliani et al., 2018).

Penelitian ini berimplikasi pada penerapan model group investigation yaitu, siswa berperan aktif dalam pembelajaran karena dihadapkan pada permasalahan yang nyata (autentik), pembelajaran bermakna, peningkatan daya ingat, belajar mandiri, dan pembelajaran berpusat pada siswa. Implikasi tersebut tentu masih memiliki beberapa kekurangan mengingat masih adanya keterbatasan pada penelitian ini. Keterbatasan yang ada pada penelitian ini yaitu, pembelajaran daring masih menyisakan adanya keterbatasan untuk mengungkap keterampilan memecahkan masalah yang akan berimplikasi pada hasil belajar siswa. Berdasarkan hal tersebut, direkomendasi pada penelitian berikutnya yaitu pembelajaran dapat dikembangkan melalui platform daring yang lebih beragam

\section{SIMPULAN}

Penerapan model pembelajaran group investigation dapat meningkatkan hasil belajar matematika siswa karena disebabkan oleh beberapa faktor yaitu model kooperatif tipe group investigation adalah 
salah satu model kooperatif. Proses pembelajarannya menggabungkan antara kerja sama dan proses investigasi dalam menyelesaikan masalah yang diberikan. Guru memberikan kesempatan siswa untuk menyampaikan pendapat, berdiskusi, dan mencari tahu kebenaran tugas yang dibuat dengan cara bertanya maupun mengemukakan ide yang mereka miliki. Pencapaian keberhasilan siswa dalam menguasai materi juga sangat dipengaruhi oleh sintaks model pembelajaran kooperatif tipe group investigation.

\section{DAFTAR PUSTAKA}

Agung, A. A. . (2010). Pengantar Evaluasi Pendidikan. Universitas Pendidikan Ganesha.

Andersen, T., \& Watkins, K. (2018). The Value of Peer Mentorship as an Educational Strategy in Nursing. Journal of Nursing Education, 57(4), 217-224. https://doi.org/10.3928/01484834-20180322-05.

Anugrah, M. (2019). Penelitian Tindakan Kelas (Langkah-Langkah Praktis Pelaksanaan Penelitian Tindakan Kelas). LeutikaPrio.

Ariadi, I. P. (2014). Pengaruh Model Pembelajaran Group Investigation (Gi) terhadap Hasil Belajar IPA KelaS IV. E-Journal Mimbar PGSD Universitas Pendidikan Ganesha, 2(1), 1-10. http://dx.doi.org/10.23887/jjpgsd.v2i1.3233.

Ayuwanti, I. (2016). Meningkatkan Aktivitas dan Hasil Belajar Matematika Menggunakan Model Pembelajaran Kooperatif Tipe Group Investigation di SMK Tuma'ninah Yasin Metro. SAP (Susunan Artikel Pendidikan), 1(2). https://doi.org/10.30998/sap.v1i2.1017.

Ayuwanti, I. (2017). Meningkatkan Aktivitas dan Hasil Belajar Matematika Menggunakan Model Pembelajaran Kooperatif Tipe Group Investigation di SMK Tuma'ninah Yasin Metro. SAP (Susunan Artikel Pendidikan), 1(2), 105-114. https://doi.org/10.30998/sap.v1i2.1017.

Darjiani, N. N. Y., Meter, I. G., \& Negara, I. G. A. O. (2015). Analisis Kesulitan-Kesulitan Belajar Matematika Siswa Kelas V dalam Implementasi Kurikulum 2013 di SD Piloting Se-Kabupaten Gianyar Tahun Pelajaran 2014 / 2015. E-Journal PGSD Universitas Pendidikan Ganesha, 3(1), 1-11. https://ejournal.undiksha.ac.id/index.php/JJPGSD/article/view/5070.

Dewi, P. P. Y., Manuaba, I. S., \& Suniasih, N. W. (2017). Pengaruh Model Pembelajaran Group Investigation Berbasis Proyek terhadap Hasil Belajar IPA Siswa Kelas IV. International Journal of Elementary Education, 1(4), 264. https://doi.org/10.23887/ijee.v1i4.12957.

Febrianti, E. S., Karyadi, B., \& Kasrina, K. (2018). Penerapan Model Kooperatif Tipe-Group Investigation (Gi) Pada Materi Sistem Ekskresi Manusia untuk Meningkatkan Hasil Belajar Siswa Kelas XI IPA SMAN 8 Kota Bengkulu. Diklabio: Jurnal Pendidikan Dan Pembelajaran Biologi, 2(1), 10-14. https://doi.org/10.33369/diklabio.2.1.10-14.

Gabriele, K. M., Holthaus, R. M., \& Boulet, J. R. (2016). Usefulness of Video-Assisted Peer Mentor Feedback in Undergraduate Nursing Education. Clinical Simulation in Nursing, 12(8), 337-345. https://doi.org/10.1016/j.ecns.2016.03.004.

Han, J.-S., Baek, H. C., \& Jeong, A.-S. (2015). The Effects of Psychiatric Nursing Simulation on Anxiety and Self-confidence about Clinical Placement of Nursing Students. Journal of the Korea Academia$\begin{array}{llll}\text { Industrial Cooperation } & \text { Society, } & \text { 7812-7819. }\end{array}$ https://doi.org/10.5762/kais.2015.16.11.7812.

Irwan, N., \& Sani, R. A. (2015). Efek Model Pembelajaran Kooperatif Tipe Group Investigation Dan Teamwork Skills terhadap Hasil Belajar Fisika. Jurnal Pendidikan Fisika, 4(1), 41. https://doi.org/10.22611/jpf.v4i1.2567.

Ismiyati. (2015). Peningkatan Prestasi dan Motivasi Belajar PPKn Siswa Kelas Viii A SMP Negeri 2 Gedangsari - Gunungkidul Melalui Pembelajaran Group Investigation. 5(1). https://doi.org/10.24246/j.scholaria.2015.v5.i1.p39-56.

Jaziroh, A. (2019). Pengaruh Model Pembelajaran Kooperatif Tipe Team Accelerated Instruction (Tai) terhadap Kemampuan Pemecahan Masalah dalam Pembelajaran Matematika Materi Pola Bilangan. Hipotenusa: Journal of Mathematical Society, 1(1), 27-32. https://doi.org/10.18326/hipotenusa.v1i1.3283.

Juliawan, G. A., Mahadewi, L. P. P., \& Rati, W. R. (2017). Pengaruh Model Problem Based Learning (PBL) terhadap Kemampuan Pemecahan Masalah Matematika. Mimbar PGSD, 5(2), 1-10. http://dx.doi.org/10.23887/jjpgsd.v5i2.10881.

Kadek, N., Kusuma, D., Riastini, P. N., \& Pudjawan, K. (2017). Pengaruh Model Pembelajaran Arias terhadap Pemahaman Konsep Matematika pada Siswa Kelas V SD Negeri 1 Candikusuma. E-Journal PGSD Universitas Pendidikan Ganesha, Vol. http://dx.doi.org/10.23887/jjpgsd.v5i2.11038.

Khairani, A. L., \& Ismah. (2016). Pengaruh Model Pembelajaran Quantum Teaching Tipe Tandur 
Diintegrasikan dengan Kartu Tangram terhadap Hasil Belajar Matematika Siswa. Jurnal Pendidikan Matematika \& $\quad$ Matematika., $2(1)$. https://jurnal.umj.ac.id/index.php/fbc/article/view/1642.

Kurniati, A. (2016). Pengembangan Modul Matematika Berbasis Kontekstual Terintegrasi Ilmu Keislaman. Al-Khwarizmi: Jurnal Pendidikan Matematika Dan Ilmu Pengetahuan Alam, 4(1), 43-58. https://doi.org/10.24256/jpmipa.v4i1.251.

Lestari, E., Cahyono, H., \& Awaluddin, A. (2019). Penerapan Model Pembelajaran Group Investigation pada Materi Lingkaran untuk Meningkatkan Kemampuan Berpikir Kritis. Jurnal Math Educator Nusantara: Wahana Publikasi Karya Tulis Ilmiah di Bidang Pendidikan Matematika, 5(2). https://doi.org/10.29407/jmen.v5i2.12814.

Lestari, S. (2017). Penerapan Pembelajaran Group Investigation untuk Meningkatkan Prestasi dan Keaktifan Siswa Materi Statistika. Journal of Medives, 1(2), 150-157.

Lilik, B. M. (2017). Pengaruh Model Pembelajaran Kooperatif Tipe Group Investigation terhadap Kreativitas Mahasiswa Semester I PGSD UM Surabaya pada Mata Kuliah Pengantar Manajemen Pendidikan. Pedagogia: Jurnal Pendidikan, 84. https://doi.org/10.21070/pedagogia.v6i1.598.

Maarif, S. (2015). Integrasi Matematika dan Islam dalam Pembelajaran Matematika. Infinity Journal, 4(2). https: //doi.org/10.24090/insania.v19i2.716.

Muliyantini, P., \& Parmiti, D. P. (2017). Penerapan Model Pembelajaran Group Investigation (GI) untuk Meningkatkan Hasil Belajar IPA Kelas V. Jurnal Ilmiah Sekolah Dasar, 1(2), 91. https://doi.org/10.23887/jisd.v1i2.10143.

Nadiya, N., Rosdianto, H., \& Murdani, E. (2016). Penerapan Model Pembelajaran Group Investigation (gi) untuk Meningkatkan Keterampilan Berpikir Kritis Siswa pada Materi Gerak Lurus Kelas X. JIPF (Jurnal Ilmu Pendidikan Fisika), 1(2), 49. https://doi.org/10.26737/jipf.v1i2.63.

Ningsih, F. (2019). Pengaruh Model Pembelajaran Group Investigation terhadap Kemampuan Pemecahan Masalah Siswa Kelas VIII MTSN Kabupaten Kerinci. Jurnal Cendekia: Jurnal Pendidikan Matematika, 3(2), 351-362. https://doi.org/10.31004/cendekia.v3i2.118.

Nurdin, H. S. (2016). Guru Profesional dan Penelitian Tindakan Kelas. 1(1). http://dx.doi.org/10.30983/educative.v1i1.118.

Oh, E. (2019). Research on the Effective of Peer Instruction and Students' Involvement. Asia-Pacific of Multimedia Services Convergent with Art Humanities, and Sociology, 9, 199-208. https://doi.org/10.35873/ajmahs.

Pratami, A. Z., Suhartono, S., \& Salimi, M. (2019). Penerapan Model Pembelajaran Group Investigation untuk Meningkatkan Hasil Belajar Ilmu Pengetahuan Sosial. Harmoni Sosial: Jurnal Pendidikan IPS, 6(2), 164-174. https://doi.org/10.21831/hsjpi.v6i2.23535.

Putra, P. G. N., Margunayasa, I. G., \& Wibawa, I. M. C. (2018). Pengaruh Model Pembelajaran Kooperatif Tipe Group Investigation (GI) Berbasis Lesson Study terhadap Penguasaan Konsep IPA. Jurnal Pedagogi Dan Pembelajaran, 1(2). https://doi.org/10.23887/jp2.v1i2.19329.

Rahmah, N. (2018). Hakikat Pendidikan Matematika. Al-Khwarizmi: Jurnal Pendidikan Matematika dan Ilmu Pengetahuan Alam, 1(2), 1-10. https://doi.org/10.24256/jpmipa.v1i2.88.

Sai, M. (2017). Pengaruh Model Group Investigation Berbasis Internet terhadap Hasil Belajar dan Kemampuan Digital Literasi Siswa. Harmoni Sosial: Jurnal Pendidikan IPS, 4(1), 39-54. https://doi.org/10.21831/hsjpi.v4i1.9869.

Sanjaya, H. W. (2016). Penelitian Tindakan Kelas. Prenada Media.

Stone, R., Cooper, S., \& Cant, R. (2013). The Value of Peer Learning in Undergraduate Nursing Education: A Systematic Review. ISRN Nursing, 2013(i), 1-10. https://doi.org/10.1155/2013/930901.

Supriyanto, I. (2020). Peningkatan Keterampilan Berpikir Kritis Melalui Model Pembelajaran Group Investigation (GI) Pada Siswa Sekolah Dasar. Jurnal Basicedu, 4(3), 558. https://doi.org/10.31004/basicedu.v4i3.394.

Supriyanto, I., \& Mawardi. (2020). Peningkatan Keterampilan Berpikir Kritis Melalui Model Pembelajaran Group Investigation (GI) Pada Siswa Sekolah Dasar. Jurnal Basicedu, 4(3), 524-532. https://jbasic.org/index.php/basicedu/article/view/394/pdf.

Sutrini, N. N., Suarni, N. K., \& Renda, N. T. (2013). Pengaruh Model Pembelajaran Kooperatif Tipe Group Investigation (GI) terhadap Hasil Belajar IPA Siswa Kelas V SD di Gugus 7 Tianyar. MIMBAR PGSD Undiksha, 1(1). http://dx.doi.org/10.23887/jjpgsd.v1i1.743.

Ulhusna, M., \& Diana, S. (2020). Permainan Ludo untuk Meningkatkan Keterampilan Kolaborasi Siswa dalam Pembelajaran Matematika. International Journal of Elementary Education., 4(1), 130-138. http://dx.doi.org/10.23887/ijee.v4i2.23050.

Wahyuni, N. L. P. ., Wibawa, I. M. C., \& Renda, N. . (2018). Pengaruh Model Pembelajaran Kooperatif Tipe 
Group Investigation Berbantuan Asesmen Kinerja terhadap Keterampilan Proses Sains. International Journal of Elementary Education, 202. https://doi.org/10.23887/ijee.v2i3.15959.

Wana, P. R., Pangestu, W. T., \& Agustina, D. A. (2017). Perbandingan Prestasi Belajar Matematika Siswa dengan Menggunakan Metode Pembelajaran Mind Mapping dan Direct Instruction pada Siswa Kelas V SDN Jiwan 01 Madiun. Trihayu: Jurnal Pendidikan Ke-SD-An, 3(2), 83-88. http://jurnal.ustjogja.ac.id/index.php/trihayu/article/view/837.

Widiartini, P. D. O. (2019). Pengaruh Model Pembelajaran Group Investigation Berbasis Tri Hita Karana terhadap Kompetensi Pengetahuan IPA. Jurnal Ilmiah Sekolah Dasar, 3(3). https://doi.org/10.23887/jpmu.v1i1.20762.

Widiasari, N. K. R., \& Sumantri, M. (2020). Kooperatif Tipe Group Investigation Melalui Setting Lesson Study terhadap Kompetensi Pengetahuan IPA. Jurnal Ilmiah Sekolah Dasar, 4(2), 143. https: //doi.org/10.23887/jisd.v4i2.25094.

Yuliani, E. N., Zulfah, \& Zulhendri. (2018). Kemampuan Pemahaman Konsep Matematis Siswa Kelas Viii SMPN 1 Kuok Melalui Model Pembelajaran Group Investigation. Jurnal Cendekia: Jurnal Pendidikan Matematika, 2(2), 91-100. https://doi.org/10.31004/cendekia.v2i2.51.

Zainuddin, H. (2013). Implementasi Pembentukan Karakter Bersahabat Melalui Model Pembelajaran Group Investigation. Mimbar, Jurnal Sosial Dan Pembangunan, 29(1), 69. https: //doi.org/10.29313/mimbar.v29i1.368. 